\author{
Asisit. Prof. Dr. Mirela Müller \\ Faculty of Humanties and Social Sciences \\ University of Osijek \\ Lorena Jagera 9 \\ 31000Osijek \\ E_mial:mtolic@ffos.hr \\ Mobile:+385/998327771 \\ Sabine Koch-Schneider, postdoc.student \\ University of Pforzheim \\ Deaprtment of Business School \\ Germany
}

\title{
Implementation of the Education Program for the Development of Digital Literacy for Adult Education and Increase of Economic-Educational Income - case study Croatia-Dalmatia
}

\begin{abstract}
Technology then has become a mixed bag for the tourism industry. It creates a great deal of conveniences while at the same time has been used as a way to increase revenues and to lessen customer service, especially for the education of adults in the area of digital competence for the use for advertising the tourist offer of your own units. Modern Education Programs can be a great help in overcoming digital literacy and thus helping to choose a variety of offers that offer free internet advertising. The survey was conducted on the example of Okrug municipality on the Čiovo peninsula in the period from February 2017 to April 2017. 278 private renters participated. The aim of the research was to show that the Program for the Education of Foreign Languages, a specific English language that was organized by the Municipality, contributed to the advertising of its tourist units, thereby contributing to the revenue, ie the occupancy in the number of reservations. The paper used a quantization method, a questionnaire survey. point to the fact that it is necessary to invest in the Education Program so that the older population, in particular, acquires the general level of digital literacy and foreign language learning, for the purpose of finding an adequate media for advertising and strengthening the tourist capital of a municipality.
\end{abstract}

Key words: contemporary media, advertising, education program, digital literacy, tourism capital 


\section{INTRODUCTION}

Use of media is unavoidable in everyday life; likewise in teaching profession. We can speak about use of media in instruction only when the means of material reproduction and curriculum material become information holders and intermediators for instruction (Dohmen, 1976). In a continuously changing global society, the information and communication technology evolution has been, over time, a key factor to economic development. This radically transformed the worldwide tourism industry, offering new development perspectives, especially in terms of increasing organizational competitiveness, excepally to establish tourist in Dalmatia to develop semi-tourism in Čiovo (Okrug Gornj). The revolution in ICTs has profound implications for economic and social development. It has pervaded every aspect of human life whether it is health, education, economics, governance, entertainment etc. The most important benefit associated with the access to the new technologies is the increase in the supply of information. Information is shared and disseminated to larger audience. Secondly it reduces the cost of production. Knowledge is produced, transmitted, accessed and shared at the minimum cost. Considering these advantages of technology use, it is necessary to speak about digital logic and algorithmic thinking (which takes place with the use of media as a teaching subject) (Dohmen, 2001). It is important to explore how to enable private renters to incorporate the use of media and new technologies in educational purposes, especially in the process of learning a foreign language and in advertising your apartments. Digital society implies a transformation of the traditional way of life and the economic, industrial, educational, and labor changes as well as changes of personal and individual way of existence, but also the question of the "new" partnership in the development of semi-tourism (Wolfe, 2004). The need for technological skills and knowledge in the tourismus, in the workplace, and generally in all social activities is a consequence of living in a digital environment for which Alvin Toftler coined the term "Information Age" (Farke, 2006). Advertising and the media are an inevitable part of our everyday life, and their number is growing every day and has a special role in the electronic media for advertising apartments (Aaker, 2010). However, as the offer is too large, it is necessary to choose the right place for advertisements to increase the percentage of reservations. Advertising can be defined as a type of communication whose role is to inform, inform about products or consumer services. Advertising or advertising is a paid or personal message coming from a source that can be identified (Kesić, 2003). One of the oldest 
communication tools that companies use in their communication with potential consumers through media is just ADVERTISING (Berger, 2003).. Through the media, communication is also made with PR tools. Without communication with the market, gas is being produced that affects the company's business as well as jobs across the entire advertising industry chain. Advertising on the Internet: takes a high second position on advertising profitability; during 2010 positioned right away between television advertising; according to IAB (Internet Advertising Bureau); over the past ten years internet advertising has more than tripled. 2010. god. the market was worth about 8 billion, while it now exceeds 26 billions of dollars ${ }^{1}$. Search with $46 \%$ occupies the largest share in internet advertising. With search, a large share of banners, $24 \% .^{2}$

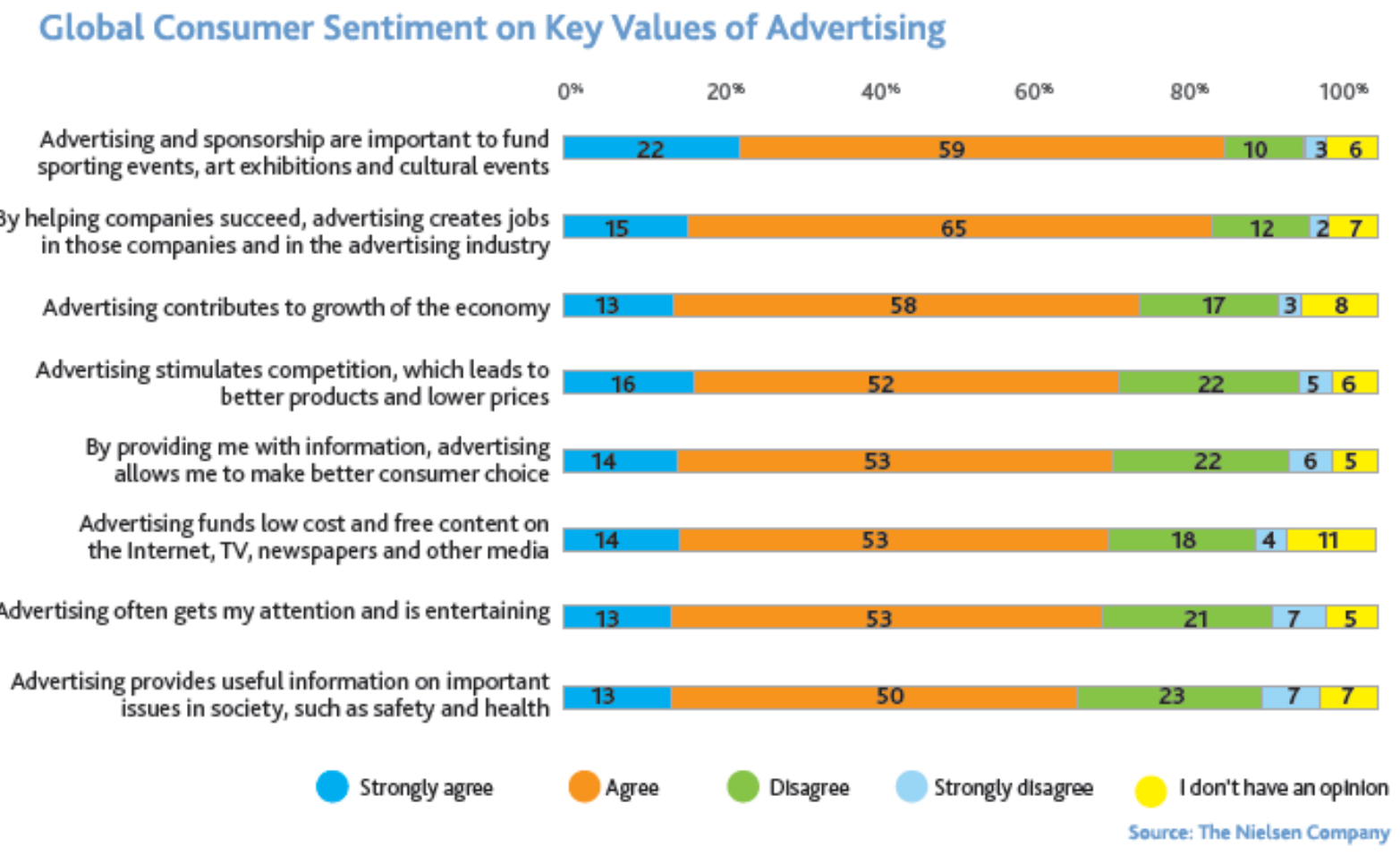

(Source: http://www.nielsen.com/us/en/insights/news/2009/consumers-worldwide-see-advertising-askey-to-economic-growth.html)

However, for the proper international advertising of apartments it is necessary knowledge of the English language. Although most of the renters do not have a professional level or general,

[1] ${ }^{1}$ Nanda,R.,Khanna, P.: (2011.). “A historical overview of marketing strategies”, International Journal of Multidisciplinary Research, Vol.1 Issue 7, 2011.

[2] ${ }^{2}$ G. E. Belch, M. A. Belch(2015.). Advertising and promotion, McGraw-Hill Education, San Diego, California, SAD. 
Okrug Gornji Municipality organized a Free Language Course in 2017 that could be free of charge for all private landlords. The education program helped greatly in the advertising of the units located, and the level of the course offered was A1-C1. The landlords received an invitation from the municipalities for free participation in the learning of the English language, and the level was formed at the wish of the participants, ie A1 and A2.

\section{METHODS}

The survey was conducted on the example of Okrug municipality on the Čiovo peninsula in the period from February 2017 to April 2017. 278 ( $\mathrm{M}=196, \mathrm{~F}=82$ ) private renters participated.. Descriptive statistics were used to calculate the frequency, percentage, Hi quadrat $\left(\chi^{2}\right)$ and correlation coefficients (Cramer's V $(\rho c)$ coefficient). The survey instrument used was the first part of the questionnaire to record private renters' opinions on different variables related to various foreign english language learning tool, digital competences and the important of apout the adversting. Original Likert-type scale was used, with the following scale: $1=$ strongly disagree, $2=$ mostly disagree, $3=$ neither agree nor disagree, $4=$ mostly agree, $5=$ strongly agree. The second part of the online questionnaire consisted of nineteen questions where respondents assessed their own level of knowledge of digital competence to how to use the internet adversting for the rent ours apartmens ,on the self-evaluation of English language education and application of digital competenceand forms of education that can contribute to the development of digital competence. In matters where there was the assessment of the agreement with the following statements about the importance of digital competence of migrants what are they need to learn a foreign language, to work with new multimedia tools, and the purpose of the use of modern technology in labor market; respondents were choosing on a scale of one to five (1- completely disagree, 5- completely agree).

\subsubsection{Results}


Table 1.1. Relationship between the using adversting of privaterenters and opinion of private renters on the using the internet adversting

\begin{tabular}{|l|c|c|c|c|c|}
\hline Relationship & $\chi \mathbf{2}$ & df & p & Ф & P \\
& & & & & \\
\hline Print advertising and online advertising & 63,31 & 2 & $<0,01$ & $-0,43$ & $<0,01$ \\
\hline AIRBN and BOOKING advertising & 85,17 & 4 & $<0,01$ & $-0,31$ & $<0,01$ \\
\hline 9FLAY and Ebaykleineanzeige & 91,23 & 3 & $<0,01$ & 0,33 & $<0,01$ \\
\hline
\end{tabular}

Table 1.1. shows that the private renters who are use the print advertising has are more positive mind about the using online advertising $(\mathrm{M}=41.6, \mathrm{SD}=2.35)$ compared to respondents who are not before use the print advertising $(\mathrm{M}=43.1, \mathrm{SD}=0.47)$. Variability analysis has also show that there are differences in relation to the frequency of AIRBN with BOOKING advertising. Scheffe's test showed that there is a statistically significant difference in the number of respondents who access the Internet every day and are in contact with another multimedia advertising $(\mathrm{M}=47.9, \mathrm{SD}=2.45)$ compared to those who never use the multimedia advertising $(\mathrm{M}=34.9, \mathrm{SD}=1.54)$ and those respondents who have sometimes use the online advertising $(\mathrm{M}=39.0, \mathrm{SD}=2.54)$.

Figure1.Self-assessment of respondents on the use of English language and various forms of multimedia advertising tools for private accommodation units (\%)

Figure 1. Self-assessment of respondents on the use of English language and various forms of multimedia advertising tools for private accommodation units

\footnotetext{
4. generally disagree

3. i can not decide

2. mostly agree
} I completely agree. 
Figure 1. shows statistically significant differences and connections in the level of each of these claims that are mentioned in the table in relation to the frequency and purpose of using the English language to need of the process advertsing. The following are significant differences and high correlations among claims: methods of active foreign language to learning and in improving learning outcomes $(\mathrm{r}=.784613,5411, \mathrm{p} \leq .05)$, a using the multimedia tools for the find a new online advertising $(\mathrm{r}=.644123,6.411, \mathrm{p} \leq .05)$, and the hybrid-cooperative learning and the implications of new learning environments $(r=.411446,4521, p \leq .05)$. In the another part of the questionnaire, respondets about the importance of participating in the Education Program for the purpose of increasing the private and state economic capital, for the specificity of the tourist offer (Table 2.)

Table 2. Data representation of participants of the importance of participating in the Education Program for the purpose of increasing the private and state economic capital, for the specificity of the tourist offer (\%)

\begin{tabular}{|c|c|c|c|c|c|c|c|c|c|}
\hline Variable & $1(\%)$ & $2(\%)$ & $3(\%)$ & $4(\%)$ & $5(\%)$ & $\begin{array}{c}N= \\
\text { Total }\end{array}$ & $x^{2}$ & ${ }^{* d}$ & "p \\
\hline $\begin{array}{l}\text { for better } \\
\text { advertising of } \\
\text { units }\end{array}$ & $6 \%$ & $9 \%$ & $14 \%$ & $17 \%$ & $46 \%$ & $100 \%$ & 16.236 & 4 & 0.001 \\
\hline $\begin{array}{l}\text { to back up the } \\
\text { reservation and } \\
\text { For easier to } \\
\text { find a work }\end{array}$ & $13 \%$ & $4 \%$ & $11 \%$ & $14 \%$ & $70 \%$ & $100 \%$ & 14.236 & 3 & 0.012 \\
\hline $\begin{array}{l}\text { to properly } \\
\text { select } \\
\text { advertiser- } \\
\text { media and } \\
\text { For the purpose } \\
\text { of permanent } \\
\text { education }\end{array}$ & $13 \%$ & $9 \%$ & $11 \%$ & $16 \%$ & $51 \%$ & $100 \%$ & 21.152 & 2 & 0.011 \\
\hline $\begin{array}{l}\text { For the purpose } \\
\text { of suppressing } \\
\text { the gray } \\
\text { economy }\end{array}$ & $11 \%$ & $9 \%$ & $11 \%$ & $16 \%$ & $53 \%$ & $100 \%$ & 5.621 & 2 & 0.035 \\
\hline $\begin{array}{l}\text { for the mere } \\
\text { management of } \\
\text { private and } \\
\text { state capital }\end{array}$ & $4 \%$ & $6 \%$ & $16 \%$ & $20 \%$ & $54 \%$ & $100 \%$ & 13.135 & 4 & 0.058 \\
\hline
\end{tabular}

(Notes: Every statement in the original scale of Likert type was used with items: $1=$ strongly disagree, $2=$ disagree, $3=$ neither agree nor disagree, $4=$ mostly agree and $5=$ strongly agree) Source: authors

Table 2 shows that $70 \%$ respondents $(\mathrm{M}=0.77, \mathrm{SD}=0.44)$ most often see the purpose of the importance of participating in the Education Program for the purpose of increasing the private and state economic capital, for the specificity of the tourist offer in the variables to back up the reservation and For easier to find a work, than $54 \%$ respondents $(\mathrm{M}=0,47, \mathrm{SD}=0,49)$ for the 
mere management of private and state capital, $53 \%$ think For the purpose of suppressing the gray economy $(\mathrm{M}=0,42, \mathrm{SD}=0,41)$. A statistically significant correlation $\left(\chi^{2}=179,11, \mathrm{df}=2\right.$, $\mathrm{p}<.05$, Cramers $\mathrm{V}=.17$ ) is received and it shows that respondents who learn English and who participated in the Education Program are often more aware of the significance and the role of learning foreign language for the development of the using Internet as a the best way of advertsing. Furthermore, testing statistical significance has shown that the majority of respondents consider that it is very important to invest in digital education in order to reduce the unemployment rate (considering statistical significance it is less than $1 \%, p \leq 0.01$ ).

Table 3 points out the necessity of development of communication-marketing strategy and sets out the most important strategies that the respondents should acquire in order to incorporate the trend into the trend of the world's tourism world as quickly as possible and thus by promoting the development of capital of the same municipality.

Table 3nd The respondents' opinion on the type of communication-marketing strategy strategy that private renters should acquire

\begin{tabular}{|l|l|l|l|l|l|l|l|l|l|}
\hline Variable & $1 \%$ & $2 \%$ & $3 \%$ & $4 \%$ & $5 \%$ & Total & $\mathrm{x}^{2}$ & *df & *p \\
\hline segemntation & 16 & 17 & 21 & 21 & 25 & $100 \%$ & 11.412 & 3 & 0.005 \\
\hline $\begin{array}{l}\text { positioning of } \\
\text { tourist product }\end{array}$ & 13 & 24 & 29 & 30 & 4 & $100 \%$ & 16.45 & 2 & 0.004 \\
\hline the differentiation & 9 & 11 & 21 & 21 & 38 & $100 \%$ & 16.521 & 1 & 0.003 \\
\hline $\begin{array}{l}\text { Low cost and low } \\
\text { prices }\end{array}$ & 11 & 3 & 14 & 21 & 51 & $100 \%$ & 09.21 & 4 & 0.005 \\
\hline $\begin{array}{l}\text { measuring and } \\
\text { predicting tourist } \\
\text { market proposals }\end{array}$ & 4 & 9 & 11 & 24 & 52 & $100 \%$ & 14.13 & 5 & 0.005 \\
\hline $\begin{array}{l}\text { functional strategies } \\
\text { and programs }\end{array}$ & 3 & 21 & 16 & 21 & 39 & $100 \%$ & 13.51 & 2 & 0.002 \\
\hline $\begin{array}{l}\text { readiness to take } \\
\text { risks }\end{array}$ & & & & & & $100 \%$ & & 3 & \\
\hline $\begin{array}{l}\text { tourists value of the } \\
\text { repository }\end{array}$ & & & & & & $100 \%$ & & 2 & \\
\hline
\end{tabular}


(Legend: The original scale of the Likert type with the anchors was used with each claim: $1=$ completely disagree, $2=$ mostly disagree, $3=$ disagree or disagree, $4=$ mostly agree and $5=$ fully agree I agree)

Table 3 indicates the most important types of communication-marketing strategies that renters should possess and develop. In the first place, it is very important to realize the significance of "measuring and predicting tourist market proposals" ( $52 \%, \mathrm{M}=0.45, \mathrm{SD}=0.45)$, then "Low cost and low prices" $(51 \%, \mathrm{M}=0.61, \mathrm{SD}=0.59)$. A statistically significant correlation was obtained $(\chi 2=149.12, \mathrm{df}=3, \mathrm{p}<.05$, Cramers $\mathrm{V}=.18)$ among those who sensitized HEAD TO HEAD POSITIONING significance: (Directly competing with competitors with respect to the particular product properties on the same target part) and DIFFERENTIAL POSITIONING (a quest for smaller market niches where there is no strong competition for positioning your own product).

Figure 2. Statistical data on self-assessed respondents on the importance of digital literacy within the framework of the English Language Learning Program for the Development of the Tourist Supply of the Okrug Gornji Municipality and Increase of the Equity Capital

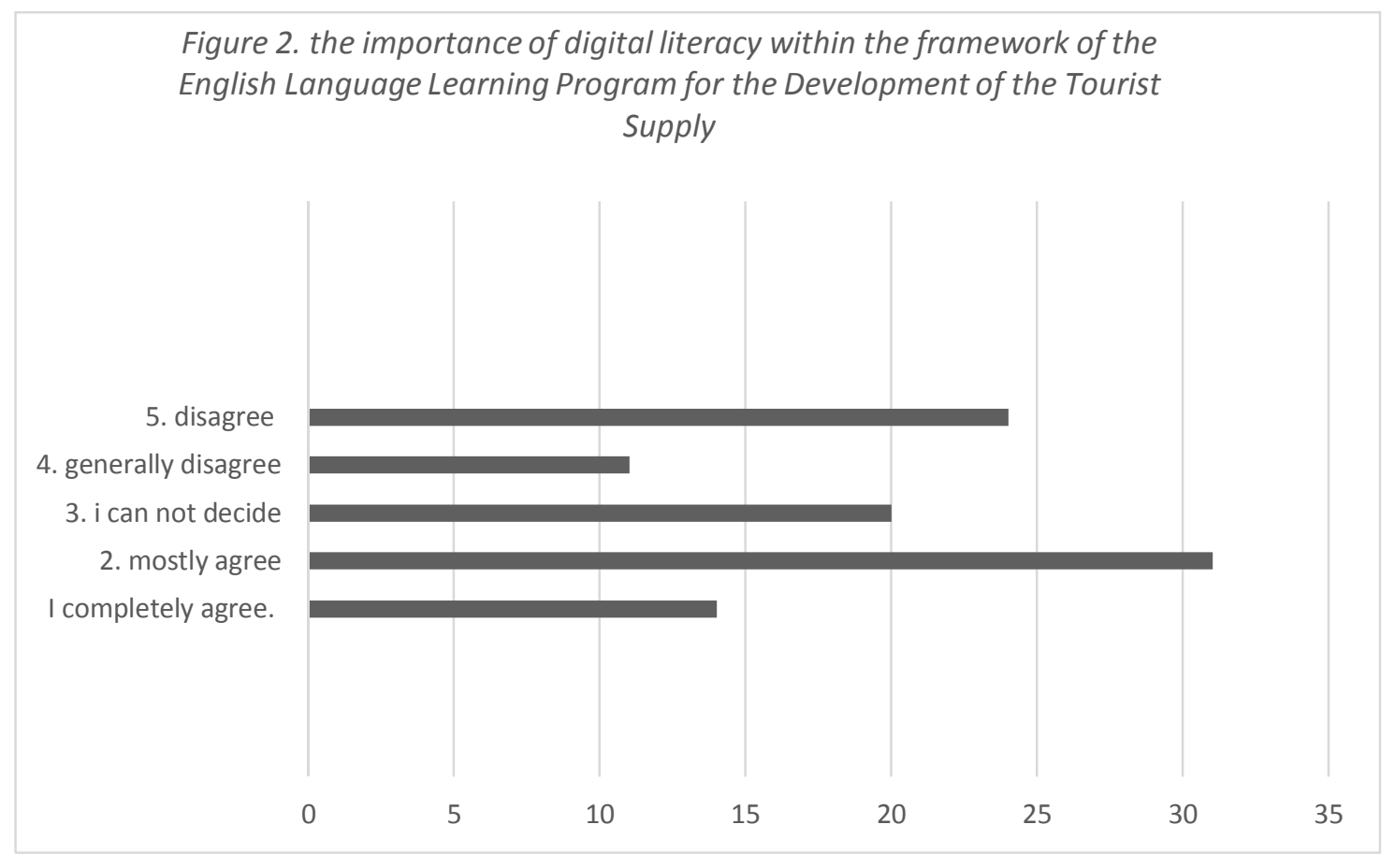

Source: Authors

Figure 2. shows the statistical data on self-assessed respondents on the importance of digital literacy within the framework of the English Language Learning Program for the Development of the Tourist Supply of the Okrug Gornji Municipality and Increase of the Equity Capital. The highest percentage is in the variable „mostly agree“ $32,45 \%$, than in the variable „disagree“ 24,89 “ and fot the variable ,i can not decide“ $20,01 \%$. This means that most of the respondents 
participating in the Education Program believe that the program acquires basic levels and some more for the use of English language and the development of digital literacy skills, as it has facilitated the selection of adequate Internet media and announces their apartments, while simultaneously increasing the economic capital tourist community of the Okrug Gornji Municipality.

Figure 4. Statistical data on respondents' opinion whether to continue the same Education Program and next year if the Okrug Municipality again organized

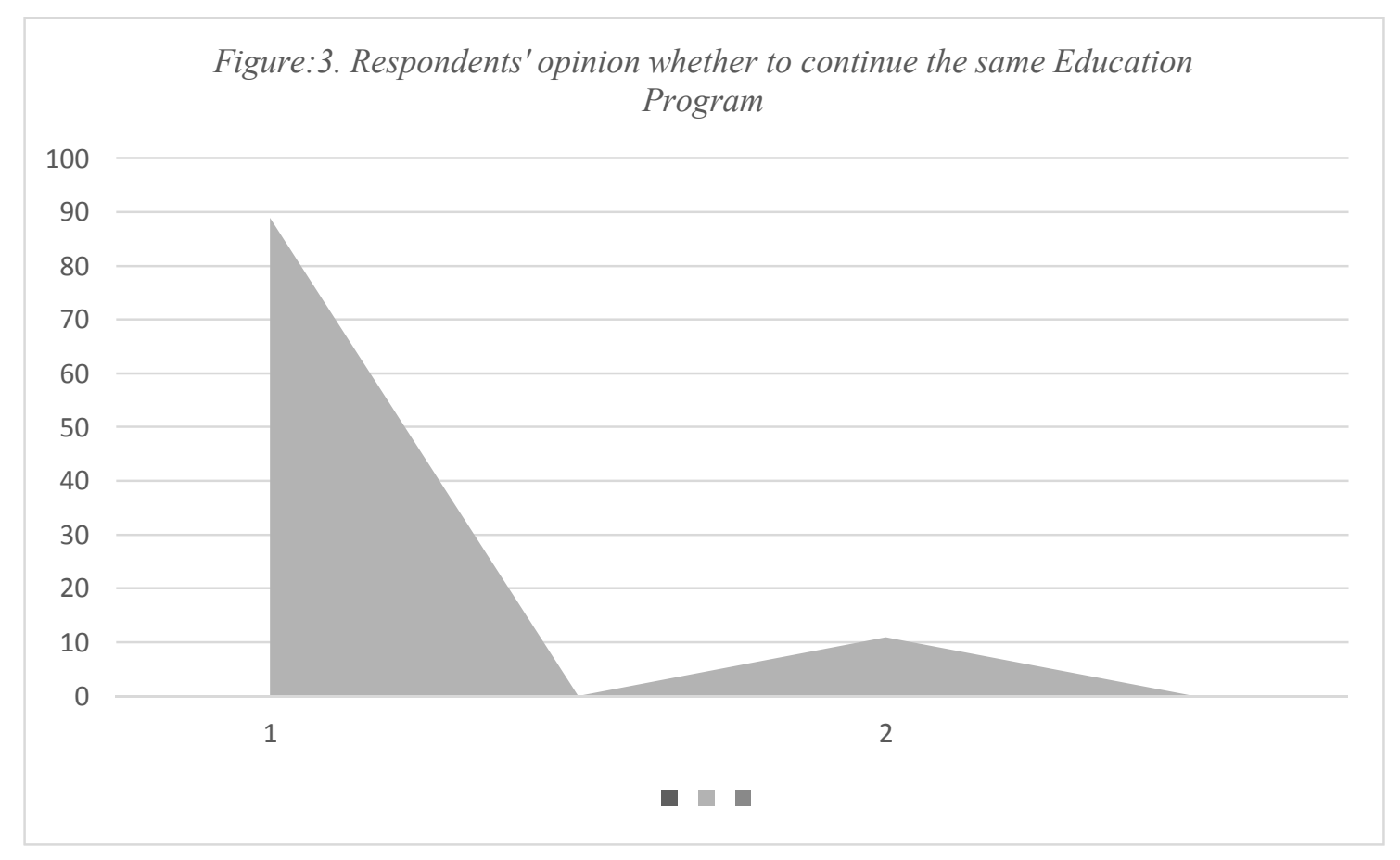

(Legend: 1. Yes, 2. No, Source: authors)

The Figure 4. show the Statistical data on respondents' opinion whether to continue the same Education Program and next year if the Okrug Municipality again organized. Most respondents $89,78 \%$ are of the opinion that they would continue the Education Program the following year because they consider the Program to be of significant benefit for apartment advertising, digital competence development and the promotion of foreign language.

The Figure 5. statistical data used by online advertisers for the purpose of renting and promoting the allocated capacities 


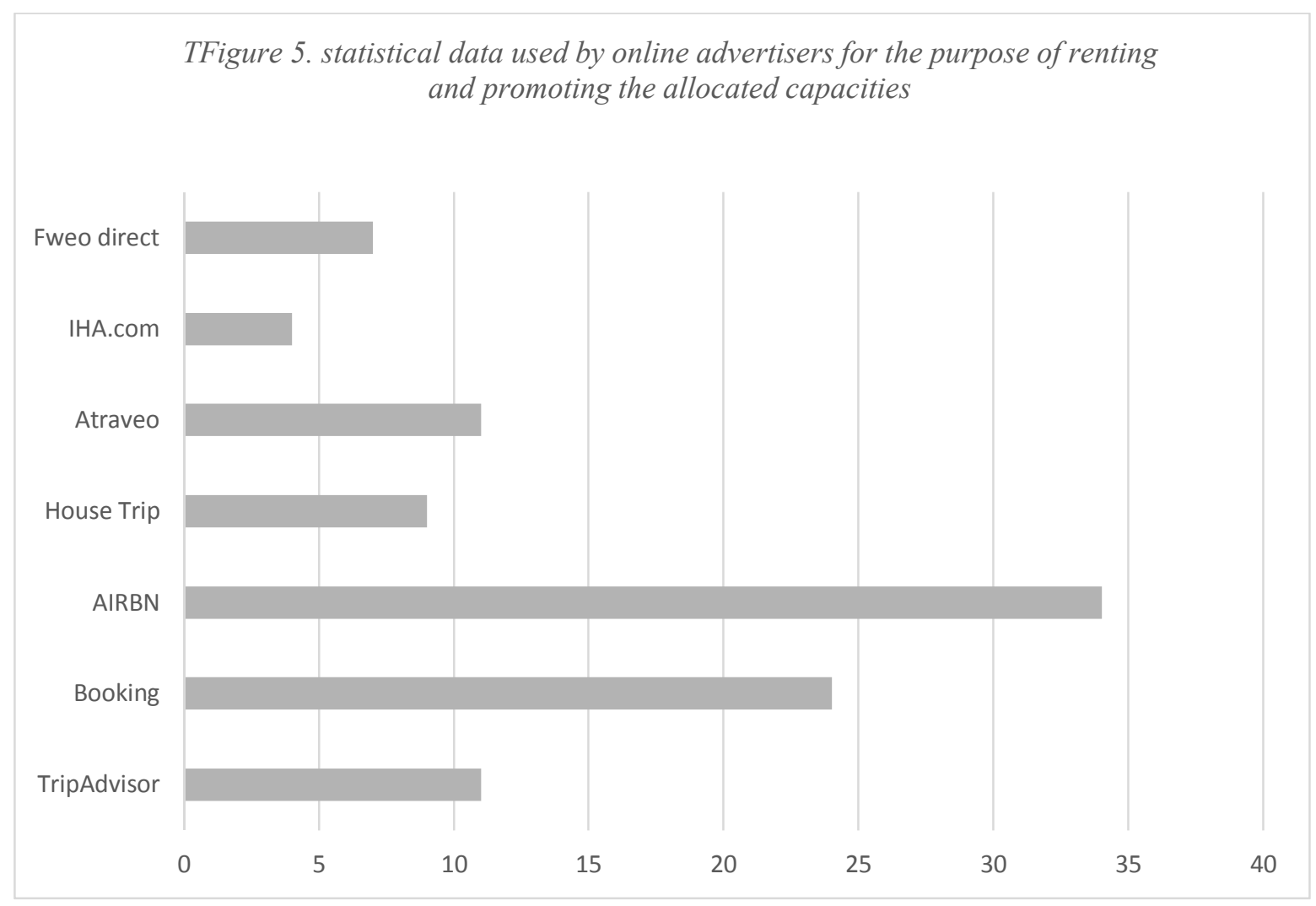

(Souce:authors)

Figure 4. shows statistical data used by online advertisers for the purpose of renting and promoting the allocated capacities. Most commonly used $\operatorname{AIBN}(34,78 \%, \mathrm{M}=0.78, \mathrm{SD}=0.54)$, than Booking.com on the second place $(24,45 \%, \mathrm{M}=0.51, \mathrm{SD}=0.54)$, than Atraveo $(12.65 \%$, $\mathrm{M}=0.36, \mathrm{SD}=0.45$ ) The following are significant differences and high correlations among claims: level of digital competence and in improving learning outcomes $(r=.614913,5411$, $\mathrm{p} \leq .05)$, a using the multimedia tools for the find a new online advertising $(\mathrm{r}=.944123,6.411$, $\mathrm{p} \leq .05)$. Table 4 shows the correlations of certain socio-economic competences that are in correlation with digital, whose correlation is necessary for the development of tourist offer, economic capital and the development of the tourist community. 
Table 4. Correlation between digital competences and socio-economic competences (they are find six correlation)

\begin{tabular}{|c|c|c|c|}
\hline $\begin{array}{c}\text { Digital } \\
\text { competences }\end{array}$ & Correlation & Chi-square & Socio-economic competences \\
\hline $\begin{array}{l}\text { Writing and } \\
\text { understanding the } \\
\text { text of a foreign } \\
\text { language through } \\
\text { multimedia tools }\end{array}$ & .364169 & $3.451, \mathrm{p} \leq .05$ & $\begin{array}{l}\text { social and economic competence for the } \\
\text { development of entrepreneurship }\end{array}$ \\
\hline $\begin{array}{l}\text { Collecting e- } \\
\text { information through } \\
\text { office tools and } \\
\text { finding out how to } \\
\text { find e-information } \\
\text { over the Internet to } \\
\text { make a better } \\
\text { advertising }\end{array}$ & .584152 & $4.811, \mathrm{p} \leq .05$ & $\begin{array}{c}\text { Opening and/or engaging in entrepreneurial } \\
\text { institutions }\end{array}$ \\
\hline $\begin{array}{c}\text { Decoding of } \\
\text { collected e- } \\
\text { information and } \\
\text { working on } \\
\text { computer software }\end{array}$ & .456377 & $1.641, \mathrm{p} \leq .05$ & $\begin{array}{l}\text { Political values and strengthening of national } \\
\text { and international identity }\end{array}$ \\
\hline $\begin{array}{l}\text { Analysis and } \\
\text { evaluation of e- } \\
\text { information of } \\
\text { advertising }\end{array}$ & .637962 & $4.631, p \leq .05$ & E- orientation \\
\hline $\begin{array}{l}\text { To know how to } \\
\text { create new media } \\
\text { for the purpose of } \\
\text { finding a the best } \\
\text { advertising }\end{array}$ & .413723 & $2.521, \mathrm{p} \leq .05$ & $\begin{array}{l}\text { Awareness for the "Networking European } \\
\text { Citizenship Education" }\end{array}$ \\
\hline $\begin{array}{c}\text { Other digital } \\
\text { competences for } \\
\text { the development of } \\
\text { personal } \\
\text { entrepreneurship }\end{array}$ & .264936 & $3.141, p \leq .05$ & $\begin{array}{c}\text { Development of business human resources } \\
\text { management }\end{array}$ \\
\hline
\end{tabular}

(Source:authors)

Table 4. shows statistically significant differences and connections in the level of each of these claims that are mentioned in the table in relation to the digital competences who can help to development the socio-economic competences. The following are significant differences and high correlations among claims: Collecting e-information through office tools and finding out how to find e-information over the Internet to make a better advertising ( $\mathrm{r}=.584152,4.811$, $\mathrm{p} \leq .05$ ), and Opening and/or engaging in entrepreneurial institutions, than of the Analysis and evaluation of e-information of advertising ( $r=.264936,3.141$., $\mathrm{p} \leq .05)$ with the $E$ - orientation; than e very high correlation with the variables To know how to create new media for the purpose of finding a job in the labor market $(\mathrm{r}=. .413726,2.521, \mathrm{p} \leq .05)$ and with the variables Awareness for the "Networking European Citizenship Education". This is primarily due to the fact that digital competences are in the ultimate connection with socio-economic competences that are very important to find a better advertising. 


\section{CONLUSION}

Starting from the very beginnings of the development of private accommodation in Dalmatia, all who started their own tourist services in their homes or other real estate faced a lack of service and detailed information and knowledge of private accommodation in one place. In particular, the need for all those who intend to deal with such tourism services has been felt. Advertising through travel agency private landlord means access to a greater number of potential guests, because of the greater role they have in marketing to allocate tourist agencies. One, depending on the quality. The services they provide can be everything: from agents who will make an entire travel plan for your guest to ordinary brokers who just pass inquiries from guest to the landlord. They work in a way to price the landlords (which they have for guests) add their own commission which can in practice be $10 \%$ pa for more, but there are also exceptions where it is smaller. Larger agencies insist that landlords leave part your earnings to add the margin to the price you could be competitive with the standard rental price which the landlord has for all guests. Through the Internet today it is over $50 \%$ of all reservations in tourism, with annual traffic over $\$ 150$ billion, and he is the main source travel information, through all stages of travel planning. The Internet is a publicly available global packet data network that connects computers together and computer networks using the Internet Protocol. "Network of all networks" consisting of millions home, academic, business and government networks that exchanging information and various services such as email, chat, file transfer, and related pages and documents World WideWeb (Kotler, 2006). For all these reasons, it is very important to use the English language and the use of digital competence. Therefore, the education program organized by the Municipality of Okrug has proved to be very useful because it has enabled private renters to acquire adequate competences in the knowledge of the English language, to acquire the basic level of digital competence to best suit the best Internet advertiser. Research has shows: that $70 \%$ respondents most often see the purpose of the importance of participating in the Education Program for the purpose of increasing the private and state economic capital, for the specificity of the tourist offer in the variables to back up the reservation and For easier to find a work; A statistically significant correlation is received and it shows that respondents who learn English and who participated in the Education Program are often more aware of the significance and the role of learning foreign language for the development of the using Internet as a the best way of advertsing. The results shoes that the most respondents $89,78 \%$ are of the opinion that they would continue the Education Program 
the following year because they consider the Program to be of significant benefit for apartment advertising, digital competence development and the promotion of foreign language. Also, the results shows the statistically significant differences and connections in the level of each of these claims that are mentioned in the table in relation to the digital competences who can help to development the socio-economic competences. The following are significant differences and high correlations among claims: Collecting e-information through office tools and finding out how to find e-information over the Internet to make a better advertising. The paper used a quantization method, a questionnaire survey. point to the fact that it is necessary to invest in the Education Program so that the older population, in particular, acquires the general level of digital literacy and foreign language learning, for the purpose of finding an adequate media for advertising and strengthening the tourist capital of a municipality.

\section{References}

[1] Beldona, S., Morrison, A. M., O’Leary, J.(2005.). "Online shostring motivations and pleasure travel products: a correspondence analysis", Tourism Management. Vol. 26. No.4; pp.561-570.

[2] Berger, H, Dittenbach, M., Merkl, D., Bogdanovych, A., Sierra, C. \& Simon, S., (2009.). "Playintg the e - business game in 3ed virtual words", OZCHI'06 Proceedings of the 18th Australia conference on „Computer-Human Interaction: Design: Activities, Artefacts and Environments“", pp. 333 - 336. doi. 10. 1145/1228175.1228237

[3] D. A. Aaker, D. McLoughlin (2010). Strategic Marketing Management, John Wiley \& Sons Ltd., West Sussex, England

[4] P. Kotler (2006.). Osnove marketinga, MATE d.o.o., Zagreb.

[5] Nanda,R.,Khanna, P.: (2011.). "A historical overview of marketing strategies", International Journal of Multidisciplinary Research, Vol.1 Issue 7, 2011.

[6] G. E. Belch, M. A. Belch(2015.). Advertising and promotion, McGraw-Hill Education, San Diego, California, SAD.

[7] T. Kesić: Integrirana marketinška komunikacija, Zagreb, 2003.

[8] http://www.emarketer.com/Article/US-Digital-Ad-Spending-WillApproach-60-BillionThis-Year-with-Retailers-Leading-Way/1012497/, avaible at 25.08.201

[9] Vidgen, R. Francis, D, Powell, P. \& Woerndl, M. (2004.). "Web service business transformation.: collaborative commerce opportunities in SMEs", Journal of Enterprise Information Management, Vol. 17.No.5.; pp.372 - 381.

[10] Wolfe, K., Hsu, C. H. C., Kang, S. K.(2004.). "Buyer characteristics among users of various travel intermediaries", Journal of Travel \& Tourism Marketing,Vol. 17, No. 2-3; pp.51-62. 